\title{
HOW OFFSHORE FINANCIAL COMPETITION DISCIPLINES EXIT RESISTANCE BY INCENTIVE-CONFLICTED BANK REGULATORS
}

\author{
Edward J. Kane
}

Working Paper 7156

http://www.nber.org/papers/w7156

\author{
NATIONAL BUREAU OF ECONOMIC RESEARCH \\ 1050 Massachusetts Avenue \\ Cambridge, MA 02138 \\ June 1999
}

The author is grateful to Richard Aspinwall, Robert Eisenbeis, Fred Furlong, Richard Herring, Stephen Kane, Charles Kindleberger, James Moser, John Pattison, and two anonymous referees for helpful criticisms of previous drafts. This paper builds on analysis contained in Kane (1991) and (1998b). All opinions expressed are those of the authors and not those of the National Bureau of Economic Research.

(C) 1999 by Edward J. Kane. All rights reserved. Short sections of text, not to exceed two paragraphs, may be quoted without explicit permission provided that full credit, including $\mathbb{C}$ notice, is given to the source. 
How Offshore Financial Competition Disciplines

Exit Resistance by Incentive-Conflicted Banks Regulators'

Edward J. Kane

NBER Working Paper No. 7156

June 1999

JEL No. G21, G28, L51

ABSTRACT

This paper studies the impact of technological change and regulatory competition on governmental efforts to generate rents for banks in two stylized regulatory environments. In the first environment, incentive-conflicted regulators attempt to create rents by restricting the size and scope of individual banking organizations. In the second, rents come from efforts to supply deposit guarantees to troubled banks. In both cases, innovations in financial technology and in competing domestic and offshore regulatory arrangements make the costs of delivering rents to banks more transparent to taxpayers and encourage customers to push rent-dependent banking systems into crisis. This analysis portrays the banking crises that have roiled world markets in recent years as information-producing events that identify and discredit inefficient strategies of regulating banking markets.

Edward J. Kane

Finance Department

Boston College

Chestnut Hill, MA 02467

and NBER

sandra.howe.2@bc.edu 


\section{HOW OFFSHORE FINANCIAL COMPETITION DISCIPLINES EXIT RESISTANCE BY INCENTIVE-CONFLICTED BANK REGULATORS}

Financial contracts promise to move wealth across time and space. Due to the difficulty of neutralizing bad luck and counterparty conflicts of interest, the economic value and enforceability of financial contracts are never certain. Even though no one can ever completely verify the accuracy or timeliness of information that purports to describe either the condition of a financial institution or the creditworthiness of a borrower or other counterparty, some parties are more informationally disadvantaged than others. Recent financial crises in Latin America, Asia, and Russia underscore the extent to which differences in information can intensify the valuation and performance risks that inhere even in straightforward banking transactions.

Rational investors recognize the uncertainty of current information and future events and try to manage its effects. Asset-valuation theory assumes that at any time investors translate whatever information they possess into an estimated probability distribution of how future events are apt to affect the flow of net earnings allocable to different financial contracts. One application of this theory is to explain the existence of financial markets and institutions as instrumentalities that lower the cost to individual firms and households of coping with questionable information and uncertain events (see Ohlson, 1987, Chapter 4).

Contemporary financial institutions offer both innovative and tried-and-true opportunities for increasing or decreasing a customer's exposures to informational risk and event uncertainty. In any given country, informationally disadvantaged parties benefit when government supervision of banking institutions can assure that the operations of these institutions are efficient, fair, and safe.

The three central tasks of bank supervisors and regulators are: (1) to control risks of fraud and contract non-performance; (2) to operate a safety net designed to control risks of fire-sale losses associated with FSF insolvencies and unjustified bank runs, and (3) to operate the fraud controls and safety net honorably and at minimum cost to taxpayers. Wall and Eisenbeis (1999) focus on conflicts that complicate the pursuit of such public-policy goals. Minimizing regulatory costs entails striking an optimal balance between the opportunity cost of government supervisory and disciplinary activities 
("current regulation") and future costs associated with variation in the probability and severity of financial crises. Economists take it as axiomatic that, if the incentives of regulators were perfectly aligned with those of taxpayers, the optimal balance would be struck.

This paper emphasizes that the balance struck by real-world regulators is distorted by the brevity of their expected time in office and influenced by side payments that regulatees and other powerful parties offer precisely to create incentive conflict. It is assumed throughout this paper that regulators earn short-term rents from adopting policies that seek simultaneously: to facilitate a flow of cheap loans to politically favored sectors; to cover up the impact that below-market loans have on banks' net worth and depositors' loss exposures; and to protect banks in one of two ways. The first method is to help banks to preserve the existing market structure by limiting outside entry through restrictions on the size, scope, and geographic origin of would-be competitors. The other method is to support weak and insolvent banks by giving them subsidized government guarantees. Support is eventually needed because the more politically directed credits a nation's banks book, the more their net worth is undermined. With such subsidies (as, e.g., in the U.S. Savings and Loan Mess), financial disaster can bubble beneath the surface for years.

The paper explains that innovations in financial technology and regulatory strategy discipline the opportunity costs of regulatory systems that are mismanaged in either of these ways. The goal of the analysis is to explain how competition from betteradapted "alien" institutions -located offshore or in a more flexibly regulated domestic sector-- hastens the breakdown of regulatory arrangements that artificially enhance shortrun bank profitability either by retarding efficient adjustments in a nation's financial market structure or by tolerating widespread insolvency among domestic competitors.

The analysis is Schumpeterian, in that ongoing technological and regulatory innovations continually shock the system. These shocks expand the margin of competition from differently regulated financial institutions and lower the costs of entering nontraditional markets or operating in distant lands. Intensified alien competition reduces the profitability of incumbent banks and enhances opportunities for 
informationally advantaged large domestic depositors in any country to protect themselves from the burdens imposed on them by misregulation.

This double-barreled impetus to alien expansion is particularly disturbing in host countries whose banking systems include a large number of economically insolvent "zombie" institutions whose survival depends crucially on government-generated rents. As the markets of such institutions are invaded, the government's ability to sustain its program of bank rents loses credibility. The situation degenerates into crisis if and when astute domestic depositors lose faith in the viability of government guarantees of zombiebank deposits. Once this occurs, the movement of domestic balances into foreign banks accelerates and zombie banks' efforts to finance the deposit outflow unmasks their hopeless condition. Progressively less and less savvy customers lose confidence in the government's ability to keep their deposits safe and this puts increasing pressure on authorities to revise and recapitalize their insolvency-resolution system.

This information-based view of the forces that determine the onset, costs, and duration of crises in misregulated financial environments provides an alternative to the classic herding models of Kindleberger (1978) and Minsky (1977) that attribute systemic crises to contagious swings in market psychology. In our misregulation theory of crisis, technological change, microeconomic imbalances, weaknesses in accountability, and distributional politics help to generate financial shocks and currency disequilibria. Introducing these elements clarifies that optimal policy staregies for managing disruptions caused by blocking information flows and stalling efficient adjustments in market structure are far different from those that would be needed to counteract hysterical mob responses to indications of banking and currency weakness.

\section{Cross-Country Competition in Regulatory Services}

As with any other economic good, a market exists for regulatory services. Potential purveyors of regulatory services are subject to market discipline from lowercost and/or higher-quality suppliers. Whenever technological change lowers the cost or raises the quality of services that can be provided by offshore regulators, the equilibrium market structure of a country's financial-regulation industry may be expected to become less autarkic. 
Regulation is a class of service valued not for itself but for the benefits it confers on those who produce and use the products of the regulated industry. In effect, financial services are supplied jointly by financial institutions and their regulators. This jointness means that international trade in financial services empowers customers to choose not just between domestic and foreign suppliers of financial products but also between hostcountry and home-country systems of regulation. Customer choice in financial services focuses not just on the stand-alone capacity of the institutions with which the customer formally deals, but also on differences in the cost and quality of the supervisory and guarantee services on which informationally disadvantaged customers rely to support the liquidity and safety of the products selected.

Like the financial-services business itself, financial regulation is a relationship business. Regulated institutions and their regulators contract to do a range of repeat business with each other for an indeterminate time. Neither party can recontract either moment to moment or transaction to transaction. For either side to dissolve the relationship, it must incur substantial switching costs.

Financial regulators seek to control the behavior of financial institutions and markets to achieve specific purposes. The cost and quality that institutional regulatees can fairly attribute to services produced by a given regulatory enterprise depend on the mix of purposes its managers pursue and on the efficiency with which these managers accumulate and deploy enterprise resources. Freer international trade in financial services increases the intensity of cross-national regulatory competition. As this competition becomes more intense, unfair and inefficient operation of regulatory enterprises becomes visible more quickly than before. The more and sooner that a truly inefficient regulator's business is transferred to the jurisdiction of a better regulator, the more and sooner deadweight burdens associated with inefficient patterns of regulatory oversight can fade away.

On one side of each regulatory relationship, regulators proffer benefits to client regulatees that engage in approved behaviors and threaten to impose penalties on regulatees that evade their rules. Although regulators seek a mix of public, bureaucratic, and private benefits, in public discussion, officials are reluctant to acknowledge the extent of their incentive conflicts. This reluctance routinely misinforms the average 
taxpayer about what is at stake in proposals to make changes either in rules or in enforcement practices.

On the other side of the relationship, regulatees look for permissible ways to influence regulators to make favorable adjustments in the net burden that the regulatory framework would otherwise impose. The existence of this reverse channel of influence reinforces the incentive conflicts that prevent regulators from being straightforward servants of the public good. Regulators' incentive conflicts help to explain why in practice consumer interests are often subordinated to producer interests (Stigler, 1971; Pelzman, 1976; Becker, 1983) and why opportunities for foreign firms to enter hostcountry financial-services markets are seldom free.

In any time and place, the operative framework of financial regulation reflects past regulator and regulatee attempts to influence one another. The interaction is simpler in a closed economy with a single regulator than it is either in a nation with multiple independent regulators or in an open economy in which foreign regulatory suppliers compete for host-country business. This is because regulatees' ability --as dissatisfied customers-- to bring pressure on a particular regulator expands as the number of inmarket regulators moves from one to many.

Social controls on the job performance of government regulators responsible for overseeing the conduct of banking business and the safety and soundness of financial institutions differ between developed and developing countries. So do institutional mechanisms for government intervention into bank lending decisions. Although creditallocation mechanisms differ between the two types of countries, we take poor information flows and incentive conflict in government policymaking to be common features. Both features delay the pace of modernization and allow bank insolvencies to reach considerable depth before they become visible to the representative depositor.

In both kinds of countries, financial regulators subject foreign banks and the foreign operations of domestic banks to patterns of regulation that differ importantly from those that apply to domestic banking activities. Three stylized asymmetries are studied here. First, most developed countries are willing to allow domestic banks to book a wider range of risks in their foreign subsidiaries than they are prepared to tolerate at home-country offices. This is because relationships with internationally active customers 
are an especially footloose part of the banking business and because politicians don't expect to confront responsibility for foreign banking losses in domestic political arenas. Second, barriers to the entry of foreign financial firms into local banking markets customarily exist, but in recent years officials both in developed regions and in many developing countries have been persuaded to relax these barriers. Third, when large or widespread insolvencies threaten, regulators are reluctant to encourage their traditional regulatees to sell their franchises to firms that operate under the aegis of a different regulator.

This paper seeks to incorporate these asymmetries into models of incentiveconflicted regulatory competition in hopes of clarifying the interaction between regulatory change and modern banking crises. The paper analyzes the effects of layering improved bank regulation in one country on top of a continuing series of technological shocks to international banking and regulatory competition. Improved regulation is defined on two dimensions: (1) adopting a strategy of promptly resolving the insolvency of zombie banks or (2) straightforwardly permitting regulatee banks to take advantage of scale and scope economies. Improved regulation is contrasted with inferior "traditional" regulatory strategies that create market rents by (1) helping zombie banks to resist pressure for exit or (2) resisting regulatee efforts to attain optimal size and scope.

To underscore the effect of regulatory lags, the technological shocks are assumed to increases scale and scope economies at offshore banks or offices more quickly than at domestic offices of host-country banks. Year by year, technological change lowers the marginal and average costs for offshore banks of coordinating overseas operations and of managing a diverse product line.

Two models are considered. In both models, banks enter from a financially sophisticated country $\mathrm{F}$ whose taxpayers have made incumbent regulators accountable to some degree for the social costs of misregulation. In the first model, the competing countries are both financially sophisticated, but one (named U for the U.S.) formally restricts the size and product lines of its domestic institutions. In $U$, how heavily these restrictions weigh on opportunities to undertake technologically driven expansions in optimal size and product lines is lessened by allocating supervisory authority over differently chartered institutions to specialized regulators. In the other model, we assume 
one country (designated as A, to stand for developing countries in Asia and Latin America) has a single regulator that is committed to strategies of exit resistance.

Table 1 lays out the technological and regulatory differences featured in the two models. In the first model, regulatory competition focuses on restrictions on bank size and scope. In the second model, regulatory competition focuses on the sustainability of government guarantees offered to depositors at troubled banks.

For concreteness, we assume that officials in U constrain the capital position and profit-making activities of its domestic banks more severely than competing foreign authorities do and more severely than safety-and-soundness considerations justify. A banking charter can be regarded as a government "license" that empowers its recipient to offer a specific range of financial services to a specific range of domestic customers. Bank charters in $U$ fail to authorize many services on which a conscientious bank could earn profits without shifting any new risks to the deposit-insurance fund.

U's limited charter creates an additional motivation for offshore banks to enter a financially sophisticated foreign region. In particular, offices that banks in U open in foreign financial centers can typically exercise a wider range of financial powers than their U.S. banking charter would directly authorize. Conversely, offices that foreign banks open in the U can often deliver "nonbank" services to local customers more straightforwardly (i.e., more cheaply) than local banks can.

In all countries, regulators are prepared at the margin to subsidize the "international competitiveness" of their client banks' offshore activity. We assume that regulatory subsidization of financial-services exports take the form of off-budget government guarantees that are conveyed implicitly to obligations being booked in the foreign offices of large home-country banks. Because the subsidies are off-budget, home-country authorities are imperfectly accountable for them. This weakness in accountability intensifies incentive conflicts that might lead regulators in $\mathrm{F}$ or $\mathrm{U}$ to delay their response to technological shocks. Agent authorities have to balance the safety-andsoundness duties they owe their taxpayer-principals against the bureaucratic advantages and laundered personal benefits that they can earn by expanding risk-shifting opportunities for internationally active domestic and foreign banks. 
This framework of technological and regulatory evolution offers a potential explanation for the delayed emergence of megabanks in the U.S. and for the character of the profitability pressures that local banks have experienced in many developing countries. It portrays local banks' market-share decline in traditional domestic markets as a function of two forces: (1) low-cost foreign banks' innovative entry into nontraditional markets and (2) strategic responses made by incumbent competitors and incentive-conflicted regulators in the invaded markets to the forecastable profit squeeze that more-efficient outside competitors can create.

\section{Market Structure of Regulatory Competition}

Individual regulatory enterprises are multiproduct firms operating in imperfectly contestable markets. A market is a body of persons carrying on extensive and at least partly voluntary transactions in a specific good or service. Baumol, Panzar, and Willig (1986) define an individual market as perfectly contestable when the costs of entering and exiting the market are zero. In a perfectly contestable market, the threat of hit-andrun entry by potential outside competitors holds profit margins to competitive levels, irrespective of the number of incumbent competitors or of the share of industry output produced by the few largest competitors.

The demand for regulatory services is derived from the demand for its regulatees' products. A particular regulator's market share may be defined as the proportionate value of overall financial-services business that is captured by the firms with which it has a regulatory relationship. When jurisdiction in particular markets is effectively shared with other regulators, it is convenient to allocate the shared business according to the expenses individual regulators incur in overseeing the shared activities.

In most democracies, the fairness and legitimacy of private and governmental regulatory actions are tested by legislative oversight and judicial review. Nevertheless, even in countries where regulatory jurisdiction overlap, one may usually identify a dominant regulatory firm. In many countries, the central bank is politically strong enough to impose some cartel-like discipline on other members of the domestic financial regulatory industry. In other countries, the ministry of finance takes the lead. However, as financial markets have globalized, even a country's dominant domestic regulator has 
had to recognize that it is increasingly constrained by competition for regulatory business with regulators from other countries.

Even in the face of globalization, a country's market for regulatory services remains imperfectly contestable --primarily because of costs associated with exit resistance initiated or supported by government regulators. This paper emphasizes that for long periods government firms can hide losses and loss exposures from taxpayers. This capacity to roll losses forward indefinitely imparts to government firms a potentially defective short-run profitability constraint. Concealing evidence of unprofitability shortcircuits taxpayer discipline. Moreover, a government regulator's ability to resist exit is strengthened by transition or switching costs that stand in the way of regulatees who might otherwise signal the existence of the regulator's unbooked losses by transferring their regulatory business to a healthier supplier.

Differences in opportunity costs can explain what and whom various regulators control. Exogenous and endogenous disturbances in the economic environment affect opportunities for regulators. Regulatees and regulators respond jointly --albeit at different speeds-- to the changing costs of entering and exiting specific financial product markets. Product-line and geographic-market expansion by regulatory suppliers follows and supports rivalry between client financial-services firms within and across countries, regions, and administrative divisions.

The theory of contestable markets unfolds from a hypothetical benchmark equilibrium in which outside firms can effect a costlessly reversible entry into any specific market. The theory emphasizes the role of entry and exit costs as constraints on private market-structure adjustment. It is assumed that in all countries financial regulators can be persuaded to sell freer entry privileges to low-cost foreign banks for an appropriate side payment. In December 1997, the willingness of the 102 members of the World Trade Organization to accommodate foreign ownership of banking, securities, and insurance firms was codified in a formal agreement. Of course, full implementation of the agreement is far in the future. In many countries, implementation will require additional political pressure to produce enabling legislation and be delayed by prolonged negotiations. 
The key assumption in this paper's application of contestability theory is that, when foreign-bank entry is first deregulated, the costs to government officials of making inefficient domestic firms exit become perversely higher. This is because when foreign entry is deregulated, authorities have personal and bureaucratic incentives to step up their support of incumbent banks (Kane, 1991). In responding this way, officials neglect a concomitant economic duty to taxpayers. If their sole goal was to minimize taxpayer risk exposure in banks, regulators should tighten their prudential supervision of domestic banks to allow individual-firm exits to ease the industry profit squeeze that foreign entry is bound to create. This delay in adapting supervisory strategy to the more globally competitive banking environment conveys regulatory forbearances that accentuate the role that implicit deposit guarantees play as an exit barrier that prolongs the lives of insolvent "zombie" institutions.

Every financial-services firm (FSF) seeks to earn a healthy return on its equity (ROE). For ROE to be positive, the FSF's return on its tangible and intangible assets (ROA) must be large enough to create a positive net interest spread over its total funding costs (ROL) over each business cycle. Net interest spread (is) is the profit margin that exists between ROA and the explicit and implicit interest paid to funds suppliers.

To attract customers, foreign entrants must offer either innovative services or better deals. As their presence expands, they put downward pressure on the profit margins and solvency of previously protected host-country banks. Because default-risk allowances are booked at least partly as current income, reported profit spreads differ from economic returns. Reported spreads rise disproportionately during business expansions and decline disproportionately (and even turn negative) during recessions.

On an opportunity-cost accounting basis, the profit squeeze renders the leastefficient domestic banks insolvent. This is merely to say that managers of these marginal banks can no longer credibly project positive future profits on their traditional banking business.

Were it not for the relief provided by explicit and implicit government guarantees of bank liabilities, the creditors of each insolvent institution would force it either to be recapitalized, liquidated, or absorbed by a stronger competitor in relatively short order. However, existing accounting systems are disinformational enough to give host-country 
regulators and bank managers considerable discretion over how quickly damaged banks' opportunity losses need to be booked and resolved. This discretion encourages insolvent banks to pressure host-country regulators to help them to resist exit as long as they can.

Modern analyses of how deposit insurance works emphasize two points. First, government officials' incentives to monitor and control risk-taking by insolvent banks are conflicted. Even in financially sophisticated countries such as the U.S. and Japan, deposit institutions serve to some extent as vehicles for allocating subsidized credit to politically favored sectors (Pomerleano, 1997; Stiglitz, 1996). No matter how much a country's politicians and regulators may concern themselves in the abstract with internalizing externalities and promoting efficiency, they can extract personal and bureaucratic reputational benefits from routing credit subsidies to grateful parties and from delaying the resolution of losses at the banks that supply the favored credits. Second, insured institutions that are allowed to operate in an insolvent condition have incentives to engage in corrupt and excessively risky lending that, on average, may be expected to deepen their insolvency, lessen the productivity of a nation's aggregate real investment, and shift responsibility for covering additional losses to taxpayers.

Regulatory resistance to winding up the affairs of troubled banks generates implicit subsidies for undercapitalized domestic institutions. These subsidies predictably lessen the initial returns that a foreign entrant can earn. Contestability theory interprets this predictable dampening or negation of an entrant's initial returns as an exit cost that temporarily slows the pace of foreign entry.

\section{Industrial-Organization Analysis of the Effects of Foreign-Bank Entry}

The European universal bank, the U.S. financial-services holding company, and the Japanese keiretsu constitute alternative ways of bringing the specialized capacities of banks, securities firms, insurance firms, and finance companies within a single organization. To abstract from charter-based differences in the character of financialinstitution services, it is convenient to conceive of financial institutions as purveyors of informational services and deal-making instruments. This lets us partition financialservices business according to customers at which various services are directed:

1. Corporate banking; 


\section{Private banking;}

3. Consumer banking.

In practice, offshore entrants into foreign financial markets have typically begun by following their corporate customers into new locales. We assume that, unlike the host-country banks already operating in these new locales, offshore entrants are not asked to serve as conduits for delivering subsidies to politically favored domestic sectors. We assume that prudent entrants open themselves to host-country customers gradually, beginning by emphasizing asset-management, transactional, and informational services for corporations and wealthy households that were not adequately available from onshore firms. This is prudent because informational advantages and management experience possessed by incumbent banks make it costly for aggressive foreign entrants (such as Japanese banks in Korea) to rapidly wean profitable customers away from a longstanding banking relationship. Except when incipient insolvency threatens, it is the relatively unpromising disaster-prone borrower who would be most eager to build a full-service relationship with an offshore institution.

Recognizing that incentive conflicts exist in host-country regulation would make to reasonable for U.S. banks to conceive of crises in host country A as opportunities for them to effect fuller entry. In fact, for U.S. banks, movement into household banking has progressed much further in countries in Latin America where crises have been more frequent than it has in Asia. When a country's system for insuring domestic bank deposits has broken down, offshore banks can lessen the need for host-country governments to alienate voters by imposing new explicit taxes to resolve insolvencies.

Offshore banks can assist along two dimensions:

1. by helping the host-country government to negotiate a package of financial assistance from foreign institutions and multinational institutions such as the IMF (Todd, 1991) and

2. by helping host-country officials to boost customer confidence by letting offshore banks absorb and recapitalize insolvent domestic banking franchises without a public accounting for the ways that host-country authorities may previously have damaged local institutions by saddling them with politically instigated loans. 
Our first model sharpens the contrast between the regulatory environments of $U$ and $\mathrm{F}$ by assuming that country $\mathrm{F}$ charters domestic banks and foreign subsidiary institutions as fully empowered universal banks. Neglecting international differences in tax rates, this assumption implies that a restricted U.S. bank's explicit earnings on its operations in developed country $\mathrm{F}$ are likely to omit the indirect contribution that foreign operations make to profits booked at home. If restricted banks use the opportunity to book innovative home-country business in their foreign offices as a way of competing for home-country business with differently chartered foreign and domestic financial firms, the indirect benefits of foreign operations in cementing home-country customer relationships are apt to be recorded as home-country profits.

Claessens, Demirguç-Kunt and Huizenga (1997) examine the extent and profitability of foreign ownership in 80 national banking markets. In line with our modelling, these authors find that foreign banks function very differently in developed and developing countries and that foreign banks report higher profits than (presumably higher-risk) domestic banks in developing countries, but earn lower returns than homecountry banks in developed-country venues.

IV. Conflicted Incentive Structures in Financial Regulation

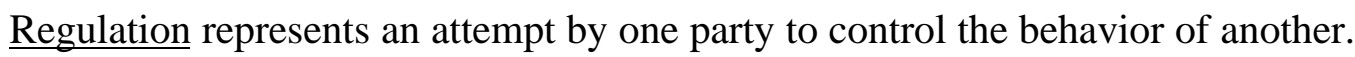
However, in financial regulation, it is sometimes hard to be sure who is the controller and who is the controllee (Stigler, 1971; Pelzman, 1976).

Regulated institutions control their regulators in several ways: by offering the "carrots" of subtle and unsubtle side payments and by threatening to wield the "lash" of public criticism and the loss of budget-generating regulatory relationships. By incurring the switching costs of executing a straightforward charter flip or engaging in a more sophisticated bit of organizational engineering, a regulated institution may migrate some or all of its future business from a burdensome regulatory environment to a more congenial one.

Regulated institutions seek benefits from their regulatory relationships. Regulatory benefits include the provision of certification and networking services that can build customer confidence and convenience and the deployment of regulatory 
controls on individual-firm entry and exit that can convey market power to the regulatees. Of course, regulatees want benefits to be produced at low cost to themselves. This puts banks on the lookout for strategies of organizational, locational, and product innovation that can reduce their firm-wide net burden of regulation (NBR).

Rewards for relaxing burdens are routinely proffered to regulators by their client base. In responding to regulatee requests and arbitrage-like organizational adjustments, regulators pursue --under statutory, budgetary, and competitive restraints-- not just their acknowledged social goals but also socially less-defensible personal and bureaucratic benefits. In rewriting their rules to confront a client innovation, regulators either reimpose or relax their net regulatory burdens. In the face of technological innovations that increase scale and scope economies, pressure for relaxations is intensified by competition for regulatory relationships from imperfectly accountable foreign purveyors of regulatory services.

The Regulatory Dialectic portrays private financial institutions and home-country and host-country regulators as locked into an unending game of strategy (Kane, 1991). Each side pursues its own goals and restraints in the knowledge that technological change is occurring and that other parties set their strategies adaptively. Our first model channels financial innovations through the Regulatory Dialectic to help us to understand decisions about how to locate and charter a U.S. bank's activities across different states and nations.

The Regulatory Dialectic offers a "struggle model" of how regulatory patterns evolve. The model establishes a parallel between regulatory competition and Hegelian sequences of conflict and change. In a Hegelian sequence, the opposition of a thesis and its antithesis produces a synthesis and each new synthesis is immediately opposed by an antithesis of its own. The opposing (i.e., antithetical) forces featured in the Regulatory Dialectic are straightforward ones: (1) attempts to impose net regulatory burdens (defined as the amount by which compliance costs exceed associated benefits) on selected private activities and (2) partially offsetting arbitrage-like avoidance activity by regulatees that seeks --often with the cooperation of an alternative regulator-- to find or devise regulatory loopholes and to put business through these loopholes in circumventive ways. Managers' purpose is to lighten their bank's firmwide net regulatory burden. Regulators' 
purposes entail tradeoffs between their overt social mission and covert bureaucratic and personal ends.

Avoidance exists whenever a regulation is burdensome, and regulatory arbitrage opportunities expand whenever innovations occur or regulatory competition intensifies. Regulatory arbitrage counters and disrupts the distributional and allocative effects of politically driven efforts to intervene in financial markets. Moreover, exposure to regulatory arbitrage underscores the incentive conflicts that regulatory officials face. With fixed technology and free trade in financial and regulatory services, competitive reregulation would impose a Law of One Net Regulatory Burden in the long run. Burdens would be equalized across regulators because otherwise high-burden regulators would eventually lose all their rents as the borders of their domain implode.

Whenever a tentative market-structure equilibrium is disturbed either by the promulgation of new rules or by technological support for new avoidance strategies, the collision of forces is renewed. Each new collision begets new regulatory schemes (reregulation) and new sets of loopholes. Under the spur of technological change and crossnational regulatory competition, incentive-conflicted re-regulation may be expected more often to narrow or to legitimize newfound loopholes than to plug them completely. As technological change or competitive reregulation pushes marginal avoidance costs below the costs of compliance and enforcement, re-regulation is pushed inexorably in the direction of deregulation.

In the face of a cost-reducing sequence of technological change, the Regulatory Dialectic envisions repeating stages of regulatory avoidance (or "loophole mining") and re-regulation, with a long-lasting equilibrium impossible to obtain. In particular, a completely deregulated state, if achieved, would almost certainly contain profitable opportunities for some players to invest in developing and wielding political clout. Incentives would exist to search for and exploit opportunities to build coalitions of firms who could at least temporarily benefit from accumulating political power and using this power to constrain the economic behavior of others.

The usefulness of the Regulatory Dialectic lies in making sense of the time patterns and character of observed sequences of financial and regulatory innovation. It emphasizes that adaptations made mutually by regulators and regulatees cumulatively 
reshape the financial environment, particularly the parts of the environment that are featured in our first model: those defined by charter-based rules, institutional structures, and product lines. The theory stresses that regulators have covert goals that tend to compromise their social mission when officials are imperfectly accountable. This incentive conflict can explain repetitive regulatory deficiencies as part of a sequence of politically constrained market-structure equilibria rather than as a series of foolish and inexplicable mistakes.

Binding regulation that forecloses legitimate profit opportunities for one set of private competitors creates incentives for less-regulated producers of substitute financial services to invade these competitors' markets. Successful regulatory arbitrageurs effectively enter the regulated market by devising innovative activities, structures, and products that use newly available technologies to cleverly substitute for regulated products. At the same time, the burdens that fall on the targeted regulatees and their customers generate bureaucratic and personal rewards for regulators who are willing to cooperate in making the binding regulation less burdensome. This mixture of regulationinduced innovation and innovation-induced re-regulation reshapes market institutions and politically imposed restraints on private financial activities in a Hegelian manner. An endless series of conflicts between alternating exercises of economic and political power is simultaneously resolved and renewed.

V. Introducing Reduced Costs of Overseas Operation into the Dialectical Process It is convenient to assume that the process starts from an initial cross-national equilibrium in banking and regulatory competition. We disturb this equilibrium by assuming a once-over improvement in the credibility of foreign guarantees and a steady advance in information, contracting, and decision-support technology. This disturbance has two effects. First, the improved technology leads the home-country corporate customers of banks in $\mathrm{U}$ and $\mathrm{F}$ to expand their real activity into additional foreign markets. Banks in $\mathrm{U}$ and $\mathrm{F}$ can now more easily extend their customer servicing capacity to follow their customers into the new locales. Second, the same technological changes progressively lower the costs of managing overseas and diverse banking operations and 
raise the sustainable long-run interest spread that large U.S. and foreign banks can anticipate earning from expanding into offshore markets.

This improved profit opportunity leads some banks to contract to offer permissibly laundered compensation (L) both to their home-country regulator (to look favorably on offshore expansion) and to their offshore regulator (to permit greater foreign penetration of offshore markets in A and F). Technological change that asymmetrically lowers the cost function of conducting foreign or interregional operations generates a war chest of value that can be used by internationally active banks in $\mathrm{U}$ and $\mathrm{F}$ to bid for new regulatory privileges at home and abroad.

The compensation that global and domestic banks are willing to offer cannot exceed (and will usually be less than) the projected present discounted value to them of the entry privileges they obtain. We suppose --purely for expositional convenience-- that rents L earned by regulators are proportional to the market shares of their regulatees, that all costs are nonjoint, and that the size of the sustainable financial revenues that can be generated each year in U, F, and A are fixed. This implies that the equilibrium costs and revenues accrued by banks chartered by each country depend on their shares of each market and that regulators' incentives to earn rents focus on market shares as well.

Of course, the kinds of costs banks from $\mathrm{U}$ incur in $\mathrm{A}$ and $\mathrm{F}$ differ importantly. In entering the financially and politically sophisticated markets of $U$ or $F$, the expenses a foreign bank incurs to cope with differences in information flows and legal structures are not much different from those it incurs at home. However, in the developing-country venue of $\mathrm{A}$, one would expect a foreign bank to find it dramatically harder to verify customer-supplied data, to judge and monitor creditworthiness, and to enforce lender rights.

Assuming that regulatory permissions can be negotiated on satisfactory terms, foreign entry makes previously segmented financial markets in U, F, and A more competitive. The long-run effect of the greater interpenetration of domestic and foreign financial markets is to change the global equilibrium market structure for both financial activity and financial regulation. But the transition time and political stress of moving to this new equilibrium is apt to increase with the amount of foreign entry involved. The optimal expansion of foreign entrants entails a politically and bureaucratically painful 
shrinking of both the market share served by higher-cost incumbent domestic competitors and the rents for domestic regulators that these incumbents generate.

By framing this shrinkage as a dangerous loss of national economic autonomy, regulatees make it easier for short-horizoned government regulators to adopt policies that delay their loss of rents by forcing taxpayers to help incumbent competitors to resist exit. When exit resistance is not highly subsidized, the transition to the new equilibrium market structure need not by itself disrupt the macroeconomy. In the absence of lifesustaining subsidies, the best opportunity for higher-cost institutions is often to negotiate a turnkey voluntary sale of their already-operating banking franchise to a lower-cost entrant. This is because takeovers create value for a would-be entrant by allowing its managers to secure and consolidate first-mover advantages for their brand name by building a strong physical presence with minimal delay. During the 1990s within the United States, takeovers have greatly smoothed market-structure adjustments both in interstate banking (Kane, 1996) and in cross-industry combinations of banking and securities firms.

However, the more strongly deposit-insurance guarantees subsidize exit resistance, the more stressful the transition to the new global equilibrium becomes for other sectors. The short-run effect of unfettered market entry by technologically welladapted low-cost out-of-market competitors is to disadvantage the host country's previously subsidized borrowing sector and to narrow interest margins in the banking markets entered. This process would facilitate the movement of real resources to domestic activities whose credit had not previously been subsidized and keep borrowing rates low until the departure of inefficient banks would have moved the financial market structure to its new long-run equilibrium.

When exit is blocked, negative profit margins increase the time and energy that threatened domestic bankers must devote to politicking and raise expected future resolution costs for host-country deposit insurers (as modelled by Hiemstra, Kane, Lutton, and Swamy, 1997). Painful pressure is exerted on both ends of bank profit margins. Fund-raising becomes tougher, as troubled firms with their backs to the wall draw on underpriced government guarantees to force unsustainably high explicit and implicit interest rates to be paid to savers. On the revenue side of the profit margin, 
competition from these same domestic firms pushes asset returns to unsustainably low levels.

Throughout any period of prolonged exit resistance, narrowed profit margins translate into below-market returns on foreign and domestic bank equity. When and as the new equilibrium market structure is reached in a given country, the return on bank equity returns to a sustainable level. The incentive structure under which regulators operate in the two countries importantly affects how quickly the temporarily belowmarket returns promote exit and re-allocate private capital and market share away from strictly domestic banks and toward more-efficient real enterprise.

The series of rolling banking crises the world has experienced during the $1980 \mathrm{~s}$ and 1990s is consistent with our model of information-revealing competition between incentive-conflicted financial regulators in developed and developing countries. Across regions as diverse as North America, Scandinavia, Eastern Europe, Latin America, and the Far East, individual-country regulators have allowed low-cost foreign entrants to expand their presence in local banking markets and gone on to subsidize the funding interest rates paid by "zombie" domestic banks whose losses from politically directed loans are covered up by accounting trickery years on end (Caprio and Klingebeil, 1996).

Exit resistance wanes in a given country when and as the depth of cumulative economic insolvencies at domestic institutions leads knowledgeable bank creditors to rationally doubt that country's taxpayers will be willing or able much longer to make taxpayers support the cumulative value of their government's implicit guarantees. At this point, deposit and capital outflows from the subsidized banking sector begin to reveal bank insolvencies even to informationally disadvantaged customers. This sudden surfacing of adverse information puts exit pressure on the troubled banks and on their previously favored borrowing customers. It also disrupts credit flows to the larger real economy in which these sectors are imbedded. The need to resolve the underlying insolvencies eventually creates takeover opportunities for efficient local competitors and allows high-tech banks from financially sophisticated countries to expand their presence in foreign retail banking by acquiring and recapitalizing insolvent host-country banking franchises. 
Applying the two models to the U.S. banking scene today clarifies that marketstructure adjustments have been moving simultaneously along three trajectories. The first trajectory entails an ongoing increase in the average size and efficiency of U.S. competitors and an ongoing expansion in the range of product offerings at large banking organizations. To analyze events within the U.S. with the first model, we need only reinterpret $\mathrm{F}$ as an alien regional or product segment of U.S. financial markets. Here, subsidized exit resistance by specialized regulators and state legislatures has largely played itself out. The wave of financial-institution megamergers that the U.S. is experiencing in the late 1990s has been unleashed by a massive reduction in governmentsupported exit resistance. Along the second path, regulatory market discipline is reducing differences in the product lines that differently chartered domestic and foreign institutions can permissibly offer customers in onshore U.S. markets. Here, equalization is slowed by residual conflicts over domestic U.S. regulatory turf and by pressure to grant foreign institutions the same privileges in the U.S. that they enjoy at home or that homecountry regulators give to U.S.-based institutions that operate on their soil. Although some incentive conflict remains, U.S. megamergers promise to help U.S. institutions to win back from foreign institutions an increased share of U.S. financial business. On the third path, U.S. institutions are competing with global banks for business in financial centers and for additional market penetration into Asia, Eastern Europe, and Latin America. This transition is uncovering a rich lode of unresolved incentive conflict between regulators and taxpayers in host countries.

\section{The Role of Regulatory Competition in U.S. Megamergers}

The net regulatory burden imposed by any regulator is the gross burden that its regulations place on regulatee profit opportunities minus the benefits regulatees receive in the form of enhancements in customer convenience, customer confidence, and market power. Regulators that impose burdensome regulations on the industry segment they supervise invite penetration of this segment's markets by more lightly regulated domestic and foreign competitors. At the same time, regulators that offer favorable burdens improve opportunities for their regulatees to enter markets in which the traditional competitors face more-oppressive regulatory burdens. 
The dialectical model of competitive reregulation draws an intuitive correspondence between a regulator's net burden and a business firm's product price. In a stationary state, this model would imply a Global Law of One Net Regulatory Burden. The idea that reregulation is a competitive process also implies that the successful de facto capture of extended powers by a favorably regulated class of institution would tend to evoke a lagged authorization of these powers by the regulators whose markets are invaded.

\section{Role of Competition Among Banking, Thrift, and Credit Union Regulators Within the U.S.}

From the day the Federal Reserve opened in 1914, Fed officials have competed for federal regulatory jurisdiction with the Office of the Comptroller of the Currency (OCC). In turn, both agencies have competed for regulatory relationships with state banking departments as well as with foreign regulators and domestic regulators in other financial sectors.

Regulatory competition encourages agency heads to issue rulings designed to reduce their clients' net burden. If scale or scope economies exist, an efficient way to do this is by steadily expanding the range of activities their clients can licitly perform or the range of customers they can serve. The literature on scale and scope economies in banking is reviewed and criticized in Ors (1998). Although the data sets studied most intensively were assembled from surveys that systematically excluded the nation's largest banks, well into the 1980s empirical research found no evidence that scale and scope economies in U.S. banking were large.

As long as scale and scope economies remained small, restrictions on bank mergers and acquisitions and on banking powers would not be expected to generate enough of a net regulatory burden to generate much avoidance activity. Conversely, if as assumed here, technological change has cumulatively increased scale and scope economies over time, the Regulatory Dialectic predicts that avoidance activity would accelerate and eventually destroy the enforceability of activity and locational restrictions and the solvency of banks whose survival depended on these restrictions.

During the 1980s and early 1990s, the leadership of both the OCC and the Fed increasingly committed themselves to expanding the businesses that banking organizations could enter, while seeking to maintain barriers that impeded the entry of securities, insurance, and nonfinancial firms into banking. The Fed focused its play on 
expanding the geographic reach and securities powers of bank holding-company (BHC) affiliates, and endeavored to keep nonbanks out of banking by restricting the character of corporations that could licitly affiliate with a bank. The OCC concentrated on expanding insurance and annuity powers for national banks and on extending the operating powers of subsidiaries directly owned by a national bank. To stabilize the incentive for statechartered institutions to switch to an OCC charter, 44 state legislatures have passed legislation --so-called "wild-card statutes" -- which either authorizes automatically or empowers state regulators to authorize their regulatees to perform any activity that becomes permissible for national banks.

Similarly, although challenged by bank-sponsored lawsuits, the National Credit Union Administration has steadily liberalized its interpretation of what links might constitute a "common bond" among credit-union members. It and Congress have also expanded the powers federal credit unions can licitly perform, including their capacity for business lending.

The powers of thrift institutions were similarly broadened in the 1980s and the Office of Thrift Supervision (and its predecessor agency) have long had the competitive ability --through what is known as the Unitary Thrift Holding Company (UTHC) loophole-- to grant a thrift charter to financial and nonfinancial corporations whose mix of activities would render them ineligible to acquire a bank. But until the S\&L insurance mess was resolved, few large diversified corporations thought it profitable to enter what threatened to be a moribund industry. For decades, the attractiveness of a thrift charter to diversified acquirers was lessened by requirements to maintain a portfolio heavily specialized in housing finance and to shoulder prospectively a substantial share of the costs of bailing out the massively insolvent Federal Savings and Loan Insurance Corporation (FSLIC) and its successor fund.

By relaxing these burdens in 1996, Congress intensified nonbank interest in the UTHC loophole as a portal into banking activities. First, Congress allowed thrifts to hold more diversified portfolios by easing the qualified thrift lender test and raising the permissible amount of commercial loans that a federal thrift could book. Second, it recapitalized the Savings Association Insurance Fund in a way that sharply lowered prospective deposit-insurance costs 
for thrifts. Vis à vis banking regulators, both changes boosted the potential regulatory market share of the Office of Thrift Supervision.

\section{The Benefits of Megamergers}

Whether one looks at the distribution of loans, deposits, or assets, foreign banks made dramatic inroads into U.S. banking markets during the 1970s and 1980s. During these same decades, most of the largest U.S. banks were displaced from lists of the top 25 banks in the world.

The theory of competitive reregulation tells us that the transfer of domestic market share to banks under the aegis of foreign regulators would dispose U.S. legislators and regulators toward helping the largest U.S. banks to expand their market share to restore their global industry ranking. Indeed, U.S. regulators were the major sponsors of the negotiations that resulted in other G-10 countries establishing risk-based capital standards that formalized traditional U.S. supervisory schemes (Wagster, 1996).

However, within the U.S., technological change had to make economies of scale and scope important enough to large banks to justify the political effort needed to overcome the domestic interests that benefited from restricting the size and market power of large banks. Limits on interstate operations were sponsored, not by competing foreign banks, but by coalitions of small domestic banks. In addition, limits on bank product lines were used within government to compartmentalize domestically jealously-guarded cross-industry regulatory and Congressional Committee domestic turf.

What sources of value are unleashed in a megamerger? Although proponents of financial megainstitutions routinely project ex ante reductions in operating costs, megamergers are seldom able to realize large resource savings ex post. This supports the hypothesis that the economies of scale and scope that banks are realizing in the 1990s come from a combination of three items: increased pricing power, revenue enhancements from geographic market extension, and increased political clout (Kane, 1998a).

A megamerger inevitably expands the range of an organization's geographic servicing capacity and its customer base. The aim of a megainstitution is not so much to lower its costs as to position itself to serve a larger segment of world markets. Like a Coke or MacDonalds, a brand name like Chase or Citigroup can be exported worldwide. It may even be that brand-based 
economies of scale and scope in marketing have to overcome diseconomies that exist in managing farflung service production and portfolio operations.

Reinforcing brand-name economies is the likelihood that net regulatory benefits increase nonlinearly with an institution's size and scope. Products carrying the brand of a U.S. megainstitution may be presumed to convey subsidized informal guarantees from the U.S. government to their users. It is hard for incentive-conflicted regulators to manage the loss exposure that such guarantees pass through to taxpayers. The larger and more important a given institution becomes, the harder it becomes for U.S. regulators to discipline. For example, the very conception of the merger between Citicorp and Travelers presumed that the partners could pressure government officials into guiding the deal around longstanding laws and rules that, on their face, would seem to outlaw the combination.

Some elements of the Citigroup merger will have to be undone unless authorities remove a series of statutory and regulatory impediments. If these impediments are not ameliorated, Citigroup could be forced either to divest itself of important insurance and securities operations or to restructure the combination to squeeze it through something like the Unitary Thrift Holding Company loophole. Precisely because the powers of thrift institutions have greatly expanded during the last 20 years, the Office of Thrift Supervision could grant Citicorp a thrift charter that would let it do most of the things it now does under a bank charter. Activities that remain impermissible could be restructured as asset securitizations or transferred to other subsidiaries of the UTHC.

VI. The Role of Disinformational Accounting in the Buildup of Banking-System Vulnerability

Framing financial crises as purely macroeconomic phenomena predisposes an analyst to attribute the onset of accounting losses and institutional collapse to swings in mob psychology (Kindleberger, 1978; Minsky, 1977). In these now-canonical models, a financial system becomes vulnerable when securities and bank loans become irrationally overvalued by the mob. The system's aggregate vulnerability becomes progressively greater the longer the mob persists in its overvaluation. Panic ensues when the mob overreacts to a real or imagined series of disruptive shocks. The excessive piercing of the overvaluation bubble leads to a panic-driven deflation in asset prices that creates bargains for level-headed investors. The eventual success these investors achieve leads mob 
psychology back into an era of good feeling that ends when boom times transport the mob's mind back to irrational optimism again.

The analysis developed in this section seeks to trace mob overvaluation of bank assets in modern economic booms to disinformation. It attributes boom-time overvaluation in large part to deceptive accounting practices at banks that are reinforced by half-true assurances from incentive-conflicted government regulators.

Disinformational activity is designed to support the unsustainably contradictory policy mix summarized in Table 2. The contradictions are rooted in redistributive interest-group competition for income-redistributing government credit subsidies. Authorities end up encouraging banks to lend on submarginal investment projects, to book the loans that finance these projects at above-market values, and to leverage their overvalued loan holdings in a vulnerability-enhancing way.

Disinformation is produced when an informed party carefully spins the facts it knows in an effort to lead less informed observers to a false conclusion. The tools of the disinformer are omission, exaggeration and mischaracterization. Unfavorable points are not allowed to register in the discussion, favorable indications are overemphasized, and the overall implications of the facts examined are deliberately misinterpreted.

The model of crisis is laid out in Table 3. This model has some features in common with Dooley (1997). Government guarantees of bank liabilities curtail depositor incentives to take action to protect themselves against overstatement of bank asset values unless and until the government's ability to make good on its guarantees comes seriously into doubt. Customer testing of bank asset values passes from unwelcome deposit outflows into open crisis when and if the bureaucracy supporting deposit guarantees begin to seize up. To ameliorate the crisis, the political system must allocate a substantial portion of the banking system's imbedded losses across stockholders, creditors, and taxpayers at home and abroad. In any short-run fixup, the larger the amount of losses that officials leave unallocated the sooner the system is apt to fall back into crisis again.

Although a banking or currency crisis usually surfaces with unpredictable suddenness, most crises percolate over a long gestation period. What the public perceives to be a "banking crisis" is best understood as the surfacing of a longstanding struggle to finance the costs of using banks as a conduit for delivering income- 
redistributing credit subsidies to favored economic sectors. In an open crisis, the struggle seeks to allocate across society an unpaid bill for opportunity losses that have accumulated or are still accumulating at banks. In managing an open banking crisis, the remedies that are available to policymakers cut a wider swath through society than prior use of preventive remedies of regulatory discipline would have. Until a breakdown actually surfaces, policymakers expect to be able to leave office with their reputations unscathed. No matter how many ounces of cure a foresighted ounce of prevention might be worth to unwary taxpayers, the short horizons of top officials make it easy for banks and politically favored borrowers to join together to restrain the exercise of preventive regulatory measures. Such a coalition undermines the case for prevention by putting heavy lobbying pressure on short-horizoned government officials and by reinforcing this pressure with well-placed side payments.

During the period of loss generation, evidence of the country's financial fragility remains fairly subtle. Bank and government accountants are urged to offset evidencebased warnings from academics and other critics with cleverly assembled flows of comforting disinformation. For banks, disinformational accounting focuses on finding ways: to distort the timing of earnings and losses; to keep losses from being posted on income statements and balance sheets; and to overstate the book values of assets and understate the book values of liabilities.

It is easy to show that booking at par a bank loan that is made at a preferential interest rate overvalues that loan. The algebra is particularly straightforward if we assume away uncertainty and suppose that the loans are perpetuities that banks expect never to call or write off. For concreteness, let us assume that the borrower pays interest at a rate that is 90 percent of the interest rate at which an informed lender would accept the loan. Even at the moment the loan is made and if no signs of trouble emerge, in the secondary market each dollar of the subsidized loan $\left(\mathrm{L}_{\mathrm{S}}\right)$ is equal to only 90 percent of the par value. Using the standard perpetuity pricing formula:

$$
L_{S}=\frac{.9 i}{i}=.90 \text {. }
$$

Suppose that in a given country each bank holds 10 percent of its assets in cash reserves and splits the rest of its assets between subsidized and unsubsidized assets. Even if no formal defaults occur on any of the assets it holds, each bank has hidden (i.e., 
"unbooked") losses that amount to 4.5 percent of reported assets. If the markdown rate implied by the interest-rate subsidy is denoted by $\mathrm{x}$ and the percentage of subsidized assets is written as $\mathrm{s}$, the hidden losses imbedded in bank assets would be (1-x)(s) times outstanding assets A. Unless they also receive subsidized deposit guarantees, private banks participating in such a credit-allocation scheme would be insolvent unless the book value of their assets (A) exceeded the market value of their deposits (D) by more than (1-x)sA. Stated generally, the market value of owners' enterprise-contributed equity position $\left(\mathrm{MV}_{\mathrm{E}}\right)$ in an unguaranteed bank would be:

$$
\mathrm{MV}_{\mathrm{E}}=\mathrm{A}-\mathrm{s}(1-\mathrm{x}) \mathrm{A}-\mathrm{D} \text {. }
$$

In the example where $s=.45$ and $x=.9$, solvency requires $M V_{E}=.955 A-D>0$, which may be rewritten as the requirement that deposits be kept from exceeding 95.5 percent of the book value of assets.

When a country's banks are pressured to book more and more subsidized loans over time, it is easy for $\mathrm{MV}_{\mathrm{E}}$ to turn negative. To get banks to participate voluntarily in such a scheme, a government must either reduce the net risk exposure of the lender by guaranteeing the timely receipt of borrower payments or it must offer participating banks other subsidies of equal or greater value. We model the case where the subsidy takes the form of offering banks deposit insurance that reduces the interest cost depositors charge the bank by $d$ percent per year. We let $\mathrm{f}$ represent the fee the government charges per dollar of deposits guaranteed. The net annual subsidy $\left(\mathrm{S}_{\mathrm{N}}\right)$ an insured bank receives for participating in the joint credit-allocation/guarantee system becomes:

$$
\begin{aligned}
\mathrm{S}_{\mathrm{N}} & =\mathrm{dD}-(1-\mathrm{x}) \mathrm{sA}-\mathrm{fD} \\
& =(\mathrm{d}-\mathrm{f}) \mathrm{D}-(1-\mathrm{x}) \mathrm{sA} .
\end{aligned}
$$

The discounted present value of projected annual subsidies may be described as the value of a bank's government-contributed net worth $\left(\mathrm{N}_{\mathrm{G}}\right)$. If the annual subsidy is expected to continue for exactly $\mathrm{T}$ years, its discounted present value can be calculated as the value of a perpetuity with coupon $\mathrm{S}_{\mathrm{N}}$ minus the present discounted value that would be lost by selling the perpetuity for forward delivery at T. Hence, if the market return on bank equity is $r_{b}$ :

$$
N_{G}=S_{N}\left\{\frac{1}{r_{b}}-\frac{1}{\left(1+r_{b}\right)^{T}}\left[\frac{1}{r_{b}}\right]\right\}=\frac{S_{N}}{r_{b}}\left[1-\left(1+r_{b}\right)^{-T}\right] .
$$


Clearly, $\mathrm{N}_{\mathrm{G}}$ comes closer and closer to the perpetuity value $\mathrm{S}_{\mathrm{N}} / \mathrm{r}_{\mathrm{b}}$ as $\mathrm{T}$ becomes larger and larger.

As an intangible going-concern value, $\mathrm{N}_{\mathrm{G}}$ is part of the market capitalization (MC) of each participating bank:

$$
\mathrm{MC}=\mathrm{MV}_{\mathrm{E}}+\mathrm{N}_{\mathrm{G}}
$$

Whenever a bank is allowed to operate with negative $M V_{E}, N_{G}$ must be larger in magnitude than $\mathrm{MV}_{\mathrm{E}}$. When enterprise-contributed equity is negative, a bank may be described as a "zombie" institution. The zombie metaphor emphasizes the idea that an insolvent bank enjoys an unnatural existence, in that its debt and stock trade entirely on the strength of credible outside guarantees. The deeper a bank's insolvency, the more closely its owners' claim on future profits resembles a lottery ticket. The claim will pay off only as long as regulators unwisely allow dividends to be distributed or events return $M V_{E}$ to a positive value again. Returning to solvency requires the bank to earn returns large enough to erase its imbedded capital shortfall and push the value of governmentcontributed net worth back below MC again.

However, the ability of a government to deliver a gross annual subsidy equal to (d-f)D depends on taxpayer willingness and capacity to make good on its promises. To keep taxpayers from recognizing the costs that the subsidy system imposes as implicit tax obligations on the rest of society, government officials typically put a propagandistic spin on the already rosy information they receive from bank accounting reports. Their goal is to convince a trusting public that bank supervisors are on the job. Understating the size of aggregate bank losses and loss exposures serves to exaggerate the strength of government deposit-insurance reserves. During the final stages of a pre-crisis period of loss generation, government spin doctors are apt also to understate the size of ongoing declines in a country's foreign-exchange reserves and the extent of capital flight.

Of course, as the loss-generation period lengthens, visible signs of economic weakness increasingly challenge the credibility of government and bank disinformation Vis-à-vis equation (2), the projected values of both $\mathrm{S}$ and $\mathrm{T}$ fall. Visible signs of the resulting decline in $\mathrm{N}_{\mathrm{G}}$ include: the emergence of a "country premium" in the interest rates that a nation's banks must pay to foreign lenders; disappointing downturns in the 
country's credit rating and corporate profits; and downward pressure on foreign-exchange rates and the prices of domestic assets.

The slow emergence of disinformation-refuting signs of bank weakness gradually shifts the basis for rational depositor assessments of the safety of deposit claims on credit-allocating banks through three stages. In the first stage, informed depositors place increasingly less reliance on the value of each troubled bank's stockholder-contributed net worth and increasingly more reliance on at the value of explicit and implicit government guarantees of the bank's obligations. Bank runs seldom occur when bad loans and investments first convert a bank into a hopelessly insolvent "zombie" institution. This is because in the minds of a bank's creditors government guarantees can and do substitute for stockholder-contributed net worth as long as the government's capacity to shift bank losses to taxpayers remains beyond doubt.

In the second stage, the cumulative value of government guarantees grows to a worrisome size. As a result, informed depositors begin to pay more and more attention to the possibility that the government may be unable to collect the funds necessary to keep bank creditors whole. Doubts surfacing about authorities' willingness or ability to force taxpayers to bond the liabilities of an economically insolvent banking system motivate a series of "silent runs." These silent runs begin when the nation's most sophisticated depositors first recognize that assets in the country's combined banking and depositinsurance system cannot cover the claims of bank depositors unless they are supplemented by a frighteningly large injection of funds secured explicitly or implicitly by the credit of domestic or foreign taxpayers. As savvy depositors come to reinterpret past economic disinformation as a collection of deliberately misleading claims, they have a growing incentive to test the government's willingness to bail out bank depositors. They do this by demanding that their bank either pay them higher interest rates than other customers and/or collateralize their claims. As more depositors grasp the extent to which the aggregated resources of the banking and guarantee system are unable to cover aggregate obligations, bank runs become less silent and improved news coverage renders further government and industry disinformation harder and harder for less informed depositors to swallow. In such circumstances, the third stage of open crisis ensues. 
In modern crises, offshore banking competition has progressively shortened individual-country loss-generation periods. It has done this in at least two ways. First, even where foreign banks limit their entry into a host-country market to selected corporate and private banking services, their presence offers safe substitutes for deposits held in host-country banks. The availability of these substitutes lowers the costs to hostcountry depositors of engaging in silent runs. Second, the greater safety of the deposit substitutes offered onshore and offshore by foreign banks traces in part to the implicit and explicit performance guarantees that offshore entrants bring with them from the regulatory systems of their homelands. Liberalization of international capital movements and the globalization of banking markets inevitably put the costs and benefits that hostcountry systems generate in protecting local banks into closer competition with the guarantees produced by regulatory systems in major financial centers.

The footholds that offshore banks have scored in Asian and Latin American countries may be interpreted as evidence that a technologically driven passage to a moreglobalized market structure for financial regulation is underway. If we adopt an industrial-organization perspective, Schumpeterian theory would tell us to interpret the series of rolling financial crises experienced in the 1980s and 1990s as sequences of creative destruction. The suffering induced by each crisis is a transition cost that society pays to stop the accumulation of disinformation and to shrink the domain of a high-cost or inequitable regulator.

The short-run bad news revealed by each crisis is to size some of the inefficiencies and inequities that political maneuvering was able to produce when the government of the affected country enjoyed monopoly power in its domestic "onshore" market for regulatory services. Viewing such inefficiencies and inequities as supported by laundered side payments that the real and financial sectors channel to government officials clarifies how hard it is for taxpayers to mount a movement to write moreaccountable public-service employment contracts with government officials. Nevertheless, the good news is that, by constraining the equilibrium rents officials can use banks to extract in individual countries, increased offshore regulatory competition promises to stop the loss-generation process at an earlier date and at a less costly level. It 
can also create cross-national pressure to improve public-service employment contracts in the long run.

VII. The Impact of FDICIA and the Risk-Based Capital Agreement on International Banking Competition

Since the FDIC Improvement Act (FDICIA) was enacted in December 1991, global U.S. banks have greatly extended their charter powers by exploiting loopholes whose expansion is fostered by regulatory competition. The substantial capital positions these banks have chosen to carry suggest that their firm-wide risk exposure has increased proportionately.

In rebuilding its world standing, the U.S. banking sector has been helped by the resolution of the U.S. deposit-insurance mess. In the post-FDICIA regulatory environment, better-disciplined U.S. regulatory enterprises have expanded their jurisdiction at the expense of less-disciplined regulators such as those in Japan. The recent sharp decline in the stock-market capital of banks in other Pacific Rim countries provides evidence of failures in credit allocation and regulatory discipline in these countries as well.

The alleged desirability of "regulatory harmonization" is the watchword of international regulatory agreements such as the Basle accord on risk-based capital and of international regulatory associations such as the Bank for International Settlements and the International Organization of Securities Commissioners. However, harmonization is not a panacea. It can easily deteriorate into cartel-like arrangements that preserve across countries and across types of financial institution dysfunctional rules for dividing turf and supervising information flows and contract enforcement.

From the perspective of taxpayers, convergence to a single set of rules backed up by turf-allocating supervisory protocols is an inappropriate goal. If achieved, it would lessen the disciplinary benefits that offshore regulatory competition can have on hostcountry regulators. A more apt harmonization metaphor can be rooted in the meaning that harmony takes in esthetics. In art, harmony refers to the effect of combining two or more disparate elements into a pleasing aggregate that nevertheless preserves the individual identity of the component elements. The sound of a barbershop quartet 
illustrates the idea and clarifies the value of not trying to force every regulator either to sing precisely the same tune or to adopt the same voice quality.

In the short run, regulatory differences induce capital movements that uncover insolvencies among deposit institutions and complicate the task of measuring and controlling individual countries' money stock. But the long-run global effect of competitive reregulation is to generate more open and more robust financial systems.

Around the world, persistent defects exist in incentives for taxpayers and elected politicians to demand the informational transparency they need to monitor and minimize the long-run opportunity costs that jurisdiction-maximizing government agencies incur in producing regulatory services. Any protocol that enforces regulatory co-ordination across nations must inevitably limit the scope in individual countries for further information disclosure and competitive reregulation. The process of negotiating such a protocol is bound to introduce provisions designed to promote the personal and bureaucratic interests of the individual-country regulators who meet to craft it (Wagster, 1996). Regulators who derive personal and bureaucratic benefits from protecting their regulatees' market share will hold out for arrangements or stipulations --such as the principle of national treatment-- that reduce the winnowing force of regulatory competition (Selgin, 1996).

Globalization reduces differences in the net regulatory benefit or burden that particular regulators offers their client FSFs. As noted earlier, a client's net benefit is the net value of regulatory services received, after deducting explicit and implicit charges that inhere in its regulator's scheme of regulation. The key point to see is that --ignoring switching costs-- net, not gross burdens are what market forces equalize across countries and sectors. Gross benefits and burdens may reasonably differ as much as a country's regulatees and potentially apathetic taxpayers would be willing to tolerate.

In the past, market-segmenting elements in the country-specific character of inherited patterns of financial regulation were protected by distance-related, culturerelated, currency-related and language-related costs that serve as barriers to entry for foreign financial firms. Technological change is dramatically reducing the significance of these barriers by increasing opportunities for financial institutions to arbitrage differences in net regulatory burdens across countries. 
Regulatory competition is imposing painful adjustments on previously selfsatisfied operators of regulatory enterprises. In the end, these adjustments will produce regulatory patterns that are less resistant to market entry and exit. However, they will do this faster, the more accountable the affected regulatory enterprises can be made to be for the burdens they transfer to taxpayers.

Viewed from this perspective, the globalization of real and financial markets emerges as a process in which increasing international competition acting through country-specific regulatory crises imposes market discipline on government regulators. A technology-driven and irreversible downward trend in the costs of switching regulators and coordinating a multinational enterprise implies shrinking spheres of autonomy for economic policymakers in different countries. What is ultimately constricted is the freedom of politicians and government regulatory bureaus both to use financial institutions as a conduit for delivering political favors and to enforce rules of financial competition designed to protect the market share of insolvent or high-cost local institutions.

VIII. Policy Implications: The Importance of Improving Regulatory Incentives Democratic governments around the world respond to political pressure to protect domestic institutions from incursions by foreign competitors and to bail out important domestic enterprises (including government-owned entities) when they become insolvent. The predictability of this response leads bank creditors to infer the existence of implicit taxpayer guarantees even in societies that eschew a formal system of deposit insurance or operate without any other form of statutory safety net for financial firms.

What is missing in most countries is a timely mechanism for measuring and limiting taxpayer guarantees and for collecting user fees from institutions that receive conjectural guarantees. Taxpayer costs cannot be minimized unless regular accounting reports can be made informative enough that, day in and day out, market participants may fairly test the cost and adequacy of government guarantee programs. Informed opportunities for fair testing are needed to make regulators accountable in timely fashion for measuring, pricing, and funding all claims upon taxpayer resources. Only if authorities are regularly threatened by information-based checks on the quality of their 
performance will they have strong incentives to recapitalize explicit and implied insurance funds promptly when fund revenues and reserves first become insufficient to sustain their obligations.

Lags inherent in governmental information, monitoring, and regulatory-response systems are lengthened by the self-interested bureaucratic suppression of information concerning the changing market value of government guarantees. Such information needs to be published in transparent and timely fashion for the press and taxpayers to monitor. The bottom line is that what is not adequately measured will not be adequately managed.

Mispricing governmental guarantees serves the covert goal of increasing a particular regulator's short-run market share. But it simultaneously creates strong incentives for its regulatees to search out new forms of risk taking and for foreign financial firms and non-financial domestic institutions to devise inventive methods for folding government-guaranteed financial subsidiaries or affiliates into their organizational form. These incentives lead to an unsustainable extension of the mispriced guarantees and an eventual breakdown in the bureaucratic arrangements that support them.

Because of regulatory lags, opportunities for shifting risk onto governmental guarantors are especially great for innovative activities. Market participants that believe their own wealth to be on the line would inevitably demand that banks either disclose the information needed to evaluate their risk exposures or pay an appropriate uncertainty premium. When this demand is anesthetized by credible government guarantees, taxpayers need to insist that government regulators collect solid and timely information on the risk implications of financial activities.

Increases in a firm's market capitalization that result from mispriced and misadministered government guarantees derive from increasing the risk that the firm may fail. By expanding the risk that individual institutions will become insolvent, defective regulatory incentives can undermine not just the efficiency of risk control and certification, but the short-run stability of the world's financial system.

Offering hidden subsidies compromises a regulator's duty to taxpayers. This incentive conflict is severe when bank creditors feel safe and officials remain imperfectly 
accountable for the effects of the subsidy scheme. Recognizing incentive conflict between social and private goals lets us see repetitive regulatory deficiencies as more than a series of foolish and inexplicable mistakes.

The Regulatory Dialectic treats rolling financial crises as a form of Schumpeterian creative destruction. The globalization of banking and guarantee markets intensifies competitive reregulation. Reregulation expands opportunities for citizens to protect themselves from the cost of unsustainable banking policies, making it less costly for business corporations and wealthy investors to engage in silent runs on insolvent "zombie" banks. Silent runs by suspicious large-denomination depositors are halting the loss-shifting processes inherent in insolvent guarantee systems faster today than in the past. Rolling banking and currency crises have become so frequent in recent years and have concentrated in developing countries because advances in information and communications technology have enabled better-guaranteed institutions to invade previously segmented markets for banking services and even limited entry by foreign institutions expands opportunities for domestic citizens to test arrangements for supporting government guarantees.

The dialectical theory of information-based financial crises emphasizes that individual-country financial crises are not disastrous events that should be avoided at all cost. Each crisis is a wake-up call that signals the breakdown of an unsustainably contradictory policy mix. Because authorities have an incentive to resolve crises in ways that preserve defects in their accountability, one wake-up call is never enough. In providing funds to stabilize what they perceive to be a currency crisis, the World Bank and International Monetary Fund can avoid neutralizing the pressure that the crisis puts on a country's authorities to abandon discredited policy strategies of information flow and financial regulation by combining Bank and Fund assistance to any country with enforceable procedures for assuring the collection and disclosure of more reliable information about the future performance and condition of that country's financial institutions and regulatory system. 
TABLE 1: TWO MODELS OF OFFSHORE REGULATORY COMPETITION

First Model

Financial Technology

Regulatory Strategy

\section{Offshore Environment}

Sophisticated

Few Restrictions on

Domestic-Bank Pursuit of

Scale and Scope Economies

\section{$\underline{\text { Host-Country Environment }}$}

Sophisticated

Many Restrictions on

Domestic-Bank Pursuit of

Scale and Scope Economies

Lagging

Zombie Banks are Sustained by Coverup and Government Guarantees

\section{TABLE 2: THREE STRATEGIC ELEMENTS CHARACTERIZE THE BANKING POLICIES OF ALMOST EVERY COUNTRY IN THE WORLD TODAY:}

1. Politically-Directed Subsidies to Selected Bank Borrowers: The policy framework either requires or rewards banks for making credit available to designated classes of borrowers at a subsidized interest rate;

2. Subsidies to Bank Risk-Taking: The policy framework commits government officials to providing on subsidized terms explicit or conjectural guarantees to holders of bank liabilities;

3. Defective Monitoring and Control of the Subsidies: The contracting and reporting framework for government officials fails to make them directly accountable for controlling the size of either subsidy. 


\section{TABLE 3: DIALECTICAL VIEW OF ECONOMIC CRISES}

THESIS: Unsustainable Policy Mix

- Expansionary Monetary and Fiscal Policy vs. Relatively Fixed Exchange Rates

- Loss-Causing Credit-Allocation Schemes ("government-sabotaged loans”) vs. Government Guarantees of Bank Liabilities

ANTITHESIS: Market Discipline Tests Increasingly Expensive Government Promises to Support the Unsustainable Exchange Rate or Banking System

- $\quad$ In Currency Crises, Test $=$ Bear Raids

- $\quad$ In Banking Crises, Test $=$ Silent Runs by Savvy Depositors

SYNTHESIS: Crisis Occurs When Authorities Lose Their Nerve and Accept the Need to Change Policy Mix. The New Policy Mix Becomes a New Thesis and Is Shaped by the Political Economy of Bailouts, Recapitalizations, and Blame. 


\section{REFERENCES}

Baumol, William, John C. Panzar, and Robert Willig, 1986. "On the Theory of Contestable Markets," in New Developments in the Theory of Industrial

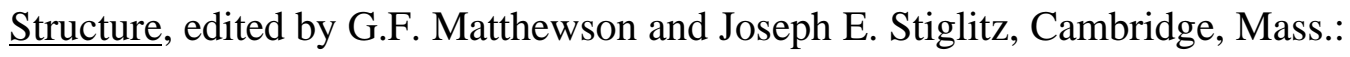
MIT Press.

Becker, Gary, 1983. "A Theory of Competition Among Pressure Groups for Political Influence," Quarterly Journal of Economics, 98(August), pp. 37-40.

Caprio, Gerald, and Daniela Klingebeil, 1996. "Bank Insolvency: Bad Luck, Bad Policy, or Bad Banking," Annual Conference on Development Economics, Washington: The World Bank, pp. 79-104.

Claessens, Stijn, Aslı Demirguç-Kunt, and Harry Huizenga, 1997. "How Does Foreign Entry Affect the Domestic Banking Market?," Washington: The World Bank Development Research Group (mimeo).

Dooley, Michael P., 1997. “A Model of Crises in Emerging Markets,” NBER Working Paper No. 6300, Cambridge, Mass.: National Bureau of Economic Research (Dec.).

Hiemstra, Stephen, Stephen Kane, Thomas Lutton, and P.A.V.B. Swamy, 1997. "A New Method of Forecasting Bank Resolutions," Washington: Office of the Comptroller of the Currency (mimeo).

Kane, Edward J., 1991. "Financial Regulation and Market Forces," Swiss Journal of Economics and Statistics, July, pp. 325-342. , 1996. "De Jure Interstate Banking: Why Only Now?," Journal of Money, Credit, and Banking, 28(May), pp. 141-161.

, 1998a. "Implication of Superhero Metaphors for the Issue of Banking Powers," Journal of Banking and Finance 22, (August 1998).

, 1998b. "Capital Movements, Asset Values, and Banking Policy in Globalized Markets," in Seongtae Lee (ed.), The Implications of Globalization of Financial Markets, Seoul, Bank of Korea Conference Proceedings, pp. 278-298.

Kindleberger, Charles P., 1978. Manias, Panics, and Crashes: A History of Financial Crises, New York: Basic Books, Inc. 
Minsky, Hyman, 1977. "A Theory of Systemic Fragility," in Edward Altman and Arnold Sametz (ed.), Financial Crises: Institutions and Markets in a Fragile Financial Environment, New York: Wiley-Interscience.

Ohlson, James A., 1987. The Theory of Financial Markets and Information, Amsterdam Elsevier Science Publishers.

Ors, Evren, 1998. The Sensitivity of Inferences About Bank Efficiency to Data-Set

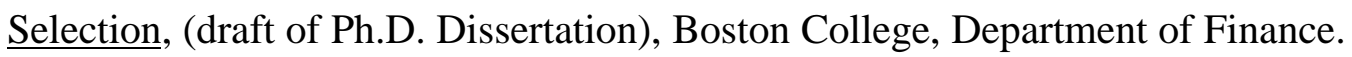

Pelzman, Sam, 1976. “Toward a More General Theory of Regulation," Journal of Law and Economics, 19(April), pp. 211-241.

Pomerleano, Michael, 1997. "The Banking Regulatory Framework in Asia - A Survey," Washington: The World Bank (unpublished draft of August 21).

Selgin, George, 1996. "Real versus Pseudo Free Trade in Banking: A Critique of NAFTA's Financial Services Provisions" in James A. Dorn and Roberto SalinasLeón (ed.), Money and Markets in the Americas: New Challenges for Hemispheric Integration, Vancouver, B.C.: The Frasier Institute, pp. 177-202.

Stigler, George, 1971. “The Theory of Economic Regulation,” Bell Journal of Economics, 1(Spring), pp. 3-21.

Stiglitz, Joseph E., 1996. "Some Lessons From the East Asian Miracle," The World Bank Research Observer 11(August), pp. 151-177.

Todd, Walker, 1991. "History of International Lending," in G. Kaufman (ed.), Research in Policy, Greenwich, CT: JAI Press, pp. 201-289.

Wagster, John D., 1996. "Impact of the Basle Accord on International Banks," Journal of Finance, 51(September), pp. 1321-1346.

Wall, Larry and Robert Eisenbeis, 1999. "Financial Regulatory Structure and the Resolution of Conflicting Goals," Journal of Financial Services, 16 (nos. 2-3), pp. 